\title{
GENERALIZATION OF PURCHASING OF PARTICULAR MATERIALS WITHIN THE CONDITIONS OF THE ARMY OF THE CZECH REPUBLIC
}

\author{
Jaromir MARES, Roman VOCHOZKA, Vaclav ZAJICEK, Daniel ZLATNIK \\ University of Defence, Brno, The Czech Republic \\ jaromir.mares@unob.cz
}

\begin{abstract}
The paper deals with the way of central purchasing of office paper of various formats and with an assessment of opportunities to generalize processes for creation of acceptable solutions. The aim is to suggest and verify opportunity for generalized processes that can be utilised within the military conditions. Basic scientific methods and statistical analysis with implication of interval classification by Sturges rule were used within the research. The findings of the research are beneficial especially for generalizing purchasing processes of other materials. This process can be used for purchasing of furniture or spare parts and accessories for military vehicles.
\end{abstract}

Keywords: central purchasing, office paper, tender price, departmental system of awarding public contracts.

\section{Introduction}

The Czech Republic, in common with contemporary Europe, is also experiencing a period, which is improving through the increase in economic growth, i.e. through expansion. With regard to the unstable situation in the world, the armed forces are given an increased confidence in the protection of the state territory and fellow citizens. This is reflected in the increased financial support to the Army. Due to enhancing their prestige, soldiers have greater motivation to defend their own country and to serve their nation. The support is mainly focused on the acquisition process for the purchase of missing advanced combat equipment. The reason for the high-quality armaments of the Army is still an imminent immigration crisis, the permanent threat of terrorist attacks, the danger and the effect of the so-called Islamic State and the ongoing Ukrainian crisis. Higher investments in the armaments of NATO partner armies are also forced by reproaches of the American side that partners within NATO fail to abide by agreements and are not equipped adequately since they do not pay the reported $2 \%$ of VAT for the military.

Despite of the improved situation in the financing of the army, it is necessary to pay attention to the efficient use of financial resources for purchases. The audits at some ministries have shown the wastage of financial resources and have highlighted the difference of acquisition prices for identical goods or services. The elimination of negatives has become a priority for the government, which aims at strengthening the application of the economy, efficiency and expediency principles (3E principles) in the management of public funds. The same also applies to the Ministry of Defence.

2. Measures, implementation of central purchasing and performance specification

The Government of the Czech Republic has approved the central public procurement 
system. Since 2012, the commodities began to be procured; they belonged to the groups of electricity, gaseous fuels, telecommunication services, office equipment and devices, computers and data processing machines, passenger cars, security services, furniture and office supplies. Each department may determine optional commodities; however, they are mandatory for the department.

In 2015, the Ministry of Finance initiated a pilot project relating to the award of an interdepartmental public contract for the supply of office paper for six ministries including the MoD as well. This is a project that is positioned hierarchically over the departmental system of central public procurement.

A standardized commodity, central purchasing of the state, central contracting entity of the state and centralised method of awarding public contracts belong to basic tools and the conceptual apparatus in the area. The central entity implements central awarding public contracts in terms of the management and acquisition of supplies or services. The supply of goods, services or construction works is a commodity. A standardized commodity is a commodity that has been determined as a commodity with a relevant standard for the central purchase of the state, approved by the Decree of the CR Government based on the negotiations of supra-departmental coordination groups. [1] [2].

According to the Decree of the CR Government [2] the Ministry of Finance has established the state central purchase of selected commodities and has decided on the standards of certain commodities within the departmental system of centralized public procurement. A list of standardized commodities has been approved and the Ministry of Finance has set an obligatory technical standard. For the time being, the central purchase at the state level relates to the purchasing of office paper within the MoD.
The supplies of office paper are implemented for six ministries, including the MoD. The order has been divided into eight parts according to the NUTS 02 regions - standards classification of territorial units. The departmental organizations of all participating ministries have been assigned to these NUTS and in each of them a contractual relationship with at least five suppliers of office paper has been created. The list of NUTS 02 is available on the website of the Ministry of Finance. [4]

For purchasing the office paper of A3 and A4 paper sizes, two types of office paper, which were purchased most over the last five years, have been chosen. It is white xerographic paper, $80 \mathrm{~g}$ of both paper sizes mentioned. The unit of measurement for the acquisition and billing data is 1 pack of 500 sheets.

The xerographic paper for copiers, laser and inkjet printers for double-sided monochrome and full-colour printing must meet technical parameters, e.g. weight, opacity, whiteness, smoothness, both-sided, colour, laser and inkjet printing and durability throughout the supply.

The price of office paper is indicated in the Annex to the Outline Agreement within the framework of particular NUTS 2 regions for all participating contractors within the class (quality) of paper. The prices are considered to be the maximum permissible and not-to-exceed prices throughout the period of execution of the public contracts awarded based of the Outline Agreement. They include transportation to the place of performance and other expenses of the contract, not explicitly mentioned, which are related to the subject of the delivery, see the table in source [5].

\section{Methods and the subject of investigation}

In the submitted article, the basic methods of analysis, synthesis, deduction and induction have been used. The special methods used in this article are mainly the method of centralized procurement and the 
statistical method that ranks among mathematical methods. Then the Sturges rule has been used to determine the number of classes - the intervals, when examining the frequency distribution:

$k \approx 1+3.3 \log n$

where $n$ is a number of values in the set.

The subject of investigation is a commodity of material group 4.1, namely office paper of A4 and A3 paper sizes.

\section{Analysis of tender prices and proposal of solution}

The analysis of tender prices is based on the data listed in Table 1. The data have been processed by basic attributes of descriptive statistics based on the submitted set from the viewpoint of its position and variability characteristics.

Table 1 Style The list of minimum tender prices according to the NUTS

\begin{tabular}{|c|c|c|c|c|}
\hline \multirow[b]{2}{*}{ NUTS } & \multicolumn{2}{|c|}{ Price [CZK] } & \multirow[b]{2}{*}{ Contractor } & \multirow{2}{*}{$\begin{array}{l}\text { Class } \\
\text { (quality) } \\
\text { paper }\end{array}$} \\
\hline & $\begin{array}{l}\text { A4 paper } \\
\text { size }\end{array}$ & $\begin{array}{l}\text { A3 paper } \\
\text { size }\end{array}$ & & \\
\hline CZ 01 Prague & 66.50 & 121.00 & $\begin{array}{l}\text { AB plus CZ } \\
\text { ASTRA }\end{array}$ & $\begin{array}{l}\mathrm{C} \\
\mathrm{C}\end{array}$ \\
\hline $\begin{array}{l}\text { CZ } 02 \\
\text { Central Bohemia }\end{array}$ & 64.13 & 128.14 & $\begin{array}{l}\text { ASTRA (A4) } \\
\text { OFFICE } \\
\text { DEPOT (A3) }\end{array}$ & $\begin{array}{l}\mathrm{C} \\
\mathrm{C}\end{array}$ \\
\hline CZ 03 Southwest & 64.74 & 129.47 & $\begin{array}{l}\text { OFFICE } \\
\text { DEPOT }\end{array}$ & $\mathrm{C}$ \\
\hline CZ 04 Northwest & 64.74 & 129.47 & $\begin{array}{l}\text { OFFICE } \\
\text { DEPOT }\end{array}$ & $\mathrm{C}$ \\
\hline CZ 05 Northeast & 67.13 & 128.26 & ASTRA & $\mathrm{C}$ \\
\hline CZ 06 Southeast & 63.53 & 122.55 & $\begin{array}{l}\text { OFFICE } \\
\text { DEPOT (A4) } \\
\text { ACTIVA (A3) }\end{array}$ & $\begin{array}{l}\mathrm{C} \\
\mathrm{C}\end{array}$ \\
\hline $\begin{array}{l}\text { CZ } 07 \\
\text { Central Moravia }\end{array}$ & 64.13 & 128.26 & ASTRA & $\mathrm{C}$ \\
\hline $\begin{array}{l}\text { CZ } 08 \text { Moravia and } \\
\text { Silesia }\end{array}$ & 62.92 & 125.84 & MICOS & $\mathrm{C}$ \\
\hline
\end{tabular}

4.1. Analysis of tender prices from the global point of view

The starting point for processing a voluminous set of data is the classification of submitted data, which may be displayed by the frequency distribution (dot plot) of tender prices as it is shown in Graph 1. 


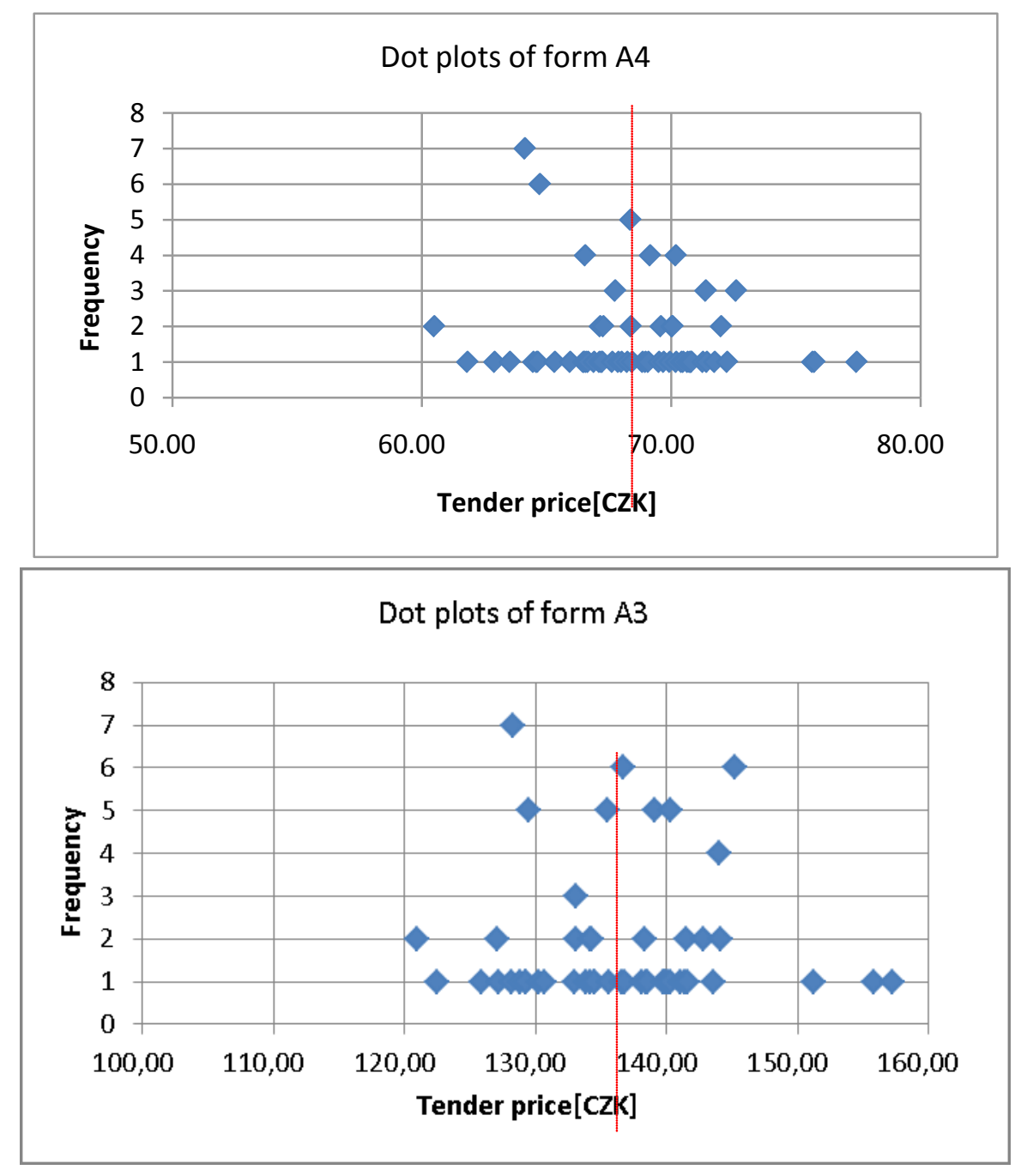

Graph 1 Frequency distribution of A4 and A3 paper sizes

It is obvious that the largest concentration of tender prices of A4 paper size occurs in the interval of 65.00 up to $70.00 \mathrm{CZK}$. For A3 paper size it is in the interval of 130.00 up to $140.00 \mathrm{CZK}$. The red line indicates the mean value of the set in the values of 68.41 CZK (A4) and 136.67 CZK (A3). The analysis will be conducted within the interval frequency distribution [6]. For A4 paper size the optimal number of intervals has been determined according to Sturges rule $k \approx 1+3.3 \log n$, where $\mathrm{n}=58$ (number of the set values) by the calculation as follows: $\mathrm{k} \approx 6.82$, which is $6-7$ intervals. The interval width is determined according to the formula $h \approx \frac{R}{k}$, where $\mathrm{R}$ is a variation range (the difference between the maximum and minimum value of the set), that is 77.44 - $60.50=10.53 \mathrm{CZK}$. The interval width is $\mathrm{h} \approx 2.48$, i.e. 2.5. For A3 paper size the optimum number of intervals have been determined when $\mathrm{n}=50$ to $\approx 6.6$, i.e. $6-7$ intervals. The variation range $\mathrm{R}=36.30$ $\mathrm{CZK}$, the width of the interval $\mathrm{h} \approx 5.5$, that is 6. Graph 2 shows the polygon and histogram of tender prices of A4 and A3 paper sizes. 

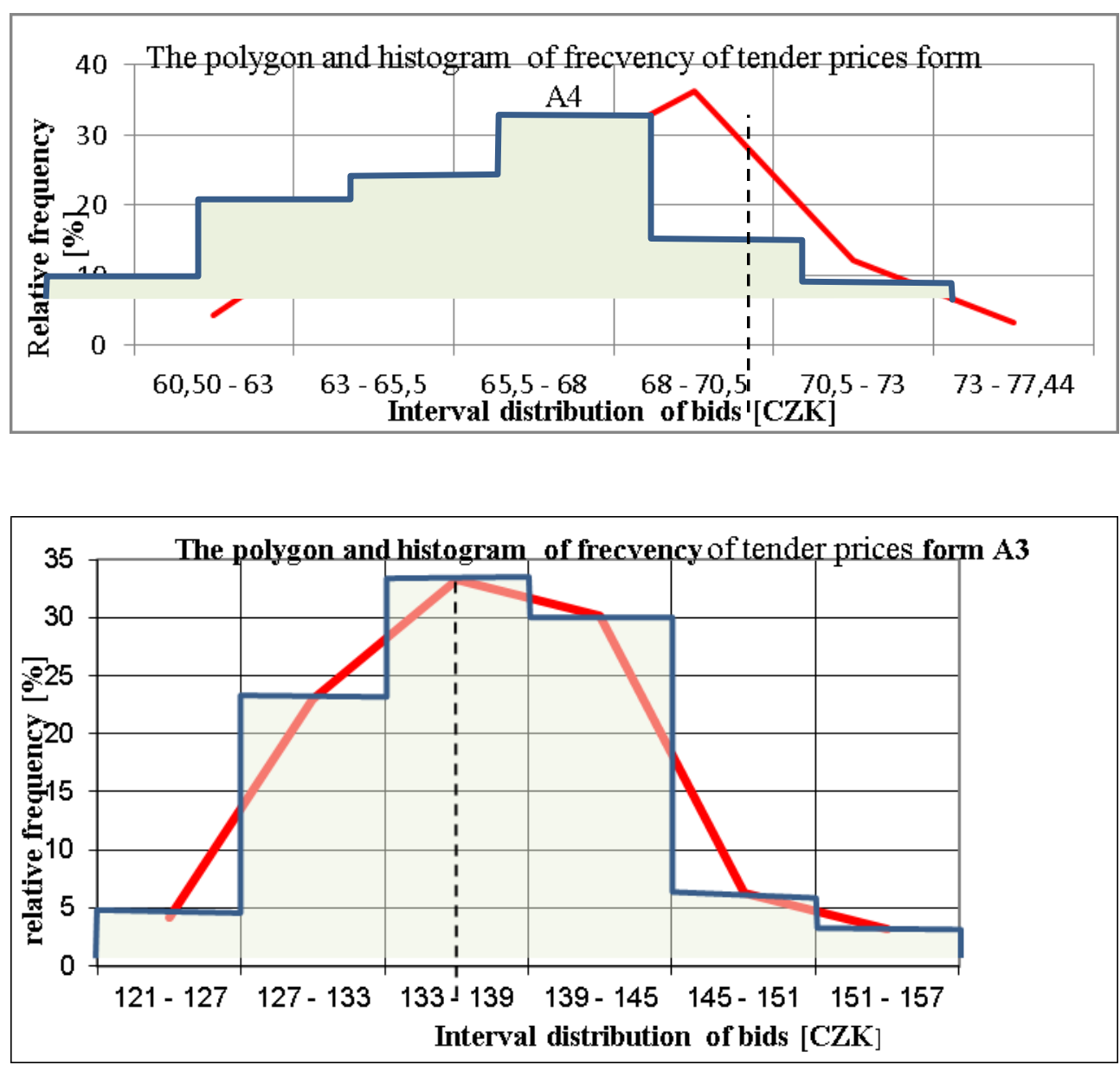

Graph 2 The polygon and histogram of $A 4$ and $A 3$ paper sizes

Both graphs show the interval frequency distribution of bids. For A4 paper size the uneven distribution is more evident than that of A3 paper size, where the majority of values lie below the mean value boundary. Tender prices are different depending on the classification of paper according to its quality. In general, it applies to both paper sizes that the highest tender prices are in quality class $\mathrm{A}$ and the lowest ones are in quality class $\mathrm{C}$. The prices are different in the bids of companies in individual NUTS 2. The lowest tender prices are recorded in CZ 01, the highest ones in CZ 04.

The lowest tender price of A4 paper size is a value of $60.50 \mathrm{CZK}$ in quality class C. A3 paper size is represented by the lowest tender price in a value of $121,-\mathrm{CZK}$, again in quality class $\mathrm{C}$. The highest tender price of both paper sizes is provided by the ACTIVA Company, that is $77.44 \mathrm{CZK}$ for
A4 paper size and $157.30 \mathrm{CZK}$ for A3 paper size, both are in quality class A.

The lowest tender price in quality class $A$ is 66.91CZK, which is offered by the AB plus CZ Company for A4 paper size. In the class mentioned, the same Company offers the lowest tender price in a value of 133.83CZK for A3 paper size.

The difference between the lowest tender prices in quality classes $\mathrm{A}$ and $\mathrm{C}$ is 6.41 CZK for A4 paper size and $12.83 \mathrm{CZK}$ for A3 paper size.

From the viewpoint of contractors, the ASTRA Company offers the lowest tender prices for both paper sizes; the ACTIVA Company offers the highest tender prices. All participating contractors offer tender prices depending on the manufacturers. This fact is a part of contracts and is subject to the inspection upon delivery. 


\subsection{Analysis of minimum tender prices}

From the viewpoint of NUTS the minimum tender prices are shown in Table 1 . According to Table 1, it is evident that the minimum tender prices predominate clearly in quality class $\mathrm{C}$ in $\mathrm{CZ} 08$ for $\mathrm{A} 4$ paper size (the MICOS Company). In CZ 01 it is the ASTRA Company for A3 paper size. From the viewpoint of frequency, of all the five contractors the ASTRA Company and the OFFICE DEPOT Company offer the lowest tender prices for both paper sizes.

\section{Possibilities of purchasing other commodities and generalization of purchase}

The analysis performed can be a basis for the acquisition of other commodities that are the subject of central purchasing of the state. In conditions of the MoD the purchases and acquisition of furniture, parts and accessories for motor vehicles are under negotiation.

The commodities mentioned are defined in the MoD rules. The centralized procurement of medical instrumentation and tools, medical supplies and commodities, which are included in the acquisition plan of central supplies applied by a property manager, is an illustrative example of the MoD. These can be purchases of e.g. tires, accumulator batteries, spare parts, equipment, ammunition, fuel and lubricants. The flow diagram in Figure 1 generalizes the analysed process.

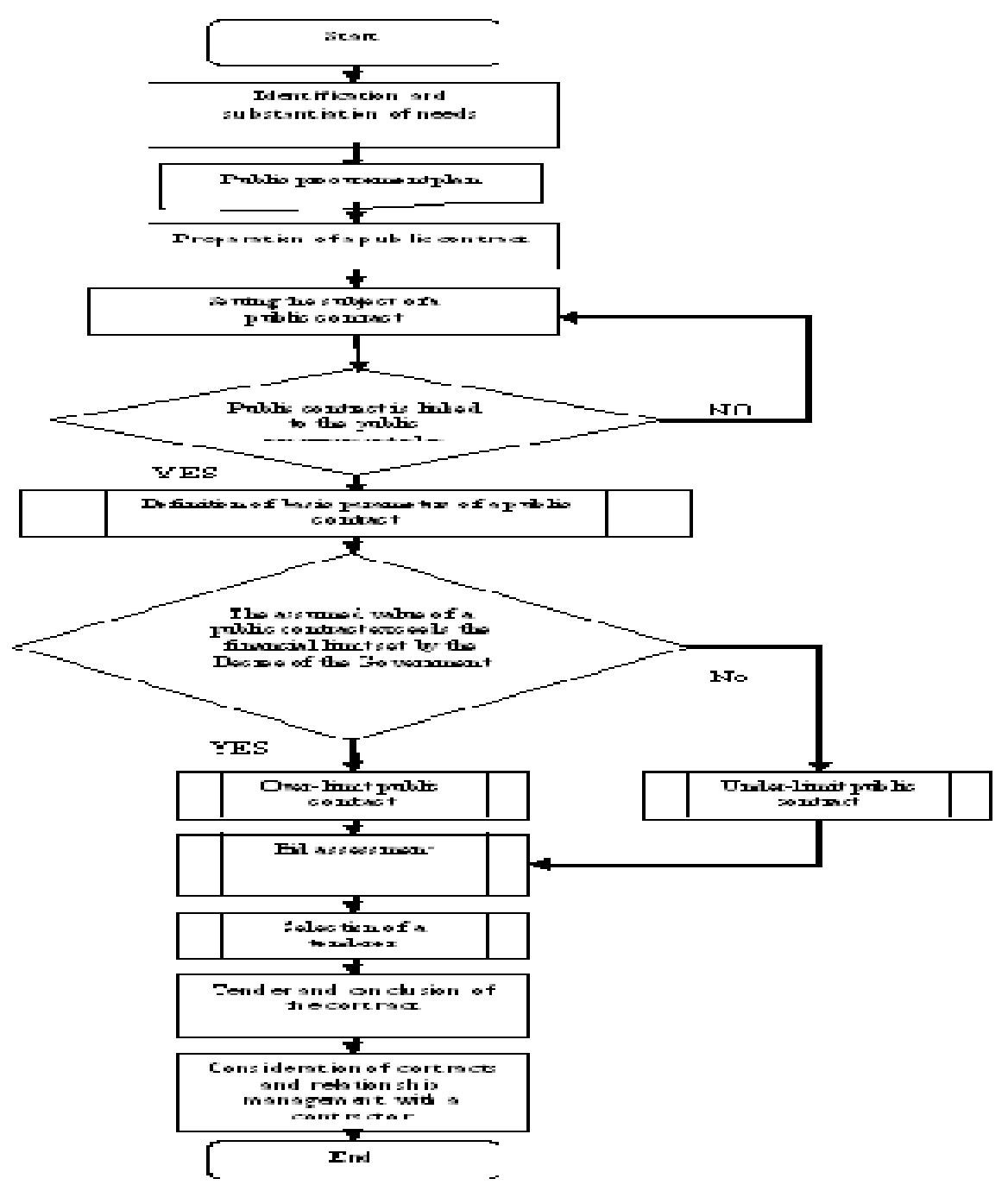

Figure 1 The flowchart of the central purchasing procedure 
The flow diagram may eventually become a basis for processing the methodological procedure of the implementation of central purchasing.

\section{Conclusions}

By analysing the tender prices of A3 and A4 paper sizes it has been found out that the lowest prices were offered in the region of CZ 01 in all the classes of paper quality. The lowest prices occurred in quality class $\mathrm{C}$ - a value of $60.50 \mathrm{CZK}$ for A4 paper size. The largest concentration of tender prices ranges from $65.00 \mathrm{CZK}$ to $70.00 \mathrm{CZK}$, i.e. in the values of tender prices of class A. For A3 paper size the lowest tender price is a value of $121.00 \mathrm{CZK}$, the highest frequency occurs in the interval of $130.00 \mathrm{CZK}$ up to $140.00 \mathrm{CZK}$, again in the values of tender prices of class A.

The submitted analysis of tender prices can be beneficial in selecting contractors according to the bids for the other uninvolved ministries and other bodies in their acquisition activities and as well as for their own analyses of the current purchase prices of the commodities in question.

The preliminary survey of the prices of an analysed commodity has also been carried out using websites. The bids of various distributors and manufacturers have been found. Based on the comparable specification, a wide range of prices that fall into the intervals of tender prices with the highest frequency are offered, as shown in Figure 1. It can be said that there are no significant discrepancies and that the previous analysis is beneficial.

Building the flowchart that presents a generalized procedure for the implementation of possible central purchasing of even other commodities is an important outcome.

\section{References}

[1] Law No. 134/2016 Sb., of the Public Procurement

[2] Minimum requirements for the operation of departmental systems of centralized procurement Czech Republic:

[3] Government resolutions of CR No. 924/2014 ze dne 12. November 2014: Annex Information of the task of Program Declaration. The introduction of central purchasing state, [online]. Praha: Government CR. 2015 [cit. 2016-08-06]. Dostupné http://www.portal-vz.cz/cs/Jak-na-zadavani-verejnych-zakazek/Centralizovane-zadavaniVZ/Legislativa

[4] Public Procurement: Dodávky kancelářského papíru pro 6 resortů [online]. Praha: Ministerstvo financí ČR, 2015 [cit. 2016-10-29]. Dostupné z: https://mfcr.ezak.cz/contract_display_1116.html.

[5] VOCHOZKA, Roman. The studies offer prices bidders supradepartmental procurement office paper. Stará Boleslav: Agentura logistiky, 2016 (Dosud nepublikováno).

[6] KŘÍŽ, Oldřich, NEUBAUER Jiří. Syllabus of lectures for statistics, skripta, Vyškov: Vysoká vojenská škola pozemního vojska, 2003, s. 40 - 41 